\title{
THOUGHT OF NUSANTARA MOSLEM SCHOLARS: FIQH \\ CONCEPTS OF SYEIKHARSYAD AL-BANJARI IN \\ SABILALMUHTADIN
}

\author{
Muhammad Roy Purwanto \\ Islamic University of Indonesia
}

Besi, Umbulmartani, Ngemplak, Sleman, Yogyakarta, Indonesia 55584

E-Mail:muhammadroy@uii.ac.id

\begin{tabular}{c|c|c}
\hline Received: & Revised: & Approved: \\
10/04/2019 & $11 / 05 / 2019$ & $10 / 06 / 2019$ \\
\hline
\end{tabular}

DOI: http:/ /dx.doi.org/10.32332/akademika.v24i1.1620

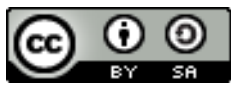

Thought Of Nusantara Moslem Scholars: Fiqh Concepts Of Syeikharsyad Al-Banjari In Sabilalmuhtadin Licensed Under a Creative Commons Attribution-ShareAlike 4.0 International License

\begin{abstract}
In the current context, the fiqh concepts of ulama nusantara(Nusantara Moslem Scholars) are important to be discussed as it has local wisdoms, progressivity, and adaptability in giving solutions to the society's problems. This paper will discuss the fiqh concepts ofSyeikhArsyad alBanjari in his book entitled SabilalMuhtadin that discusses fiqh(Islamic jurisprudence) in the perspective of Nusantara's society, especially Banjarese society. This paper uses normative-sociological approach in analyzing the fiqh concepts of SyeikhArsyad al-Banjari, such as, zakat receivers, floating lavatory, corpse burial in coffin (tabala), and providing food for mourners. The results of the study indicate that al-Banjariwas mainly relied on "custom is law" (al-adatumuhakkamah) and "generating benefits or mashlahah and declining damage" (jalb al-mashalihwadar' almafasid) in his ijtihad (independent reasoning). He also believed that law evolved according to the society's situation and condition (taghayyur alahkamyata'allaqu bi taghayyur al-azminahwa al-amkinah). All of alBanjari's concepts are in-line with Syafi'iyyah school.
\end{abstract}

Keywords: Ijtihad, Fiqh, Nusantara, and Sabilal Muhtadin 


\section{A. Introduction}

The discourse of Islam Nusantara (Islam in Indonesia) has been widely discussed in Indonesia recently. Scholars and community members discuss this subject; even, current President Joko Widodo encourages this theme to be one of international themes in Islamic model to be adopted worldwide.

Islam Nusantara is a concept of Islamic understanding which strives, negotiates, and immerses with Nusantara's culture through selection, acculturation, and adaptation processes. Islam Nusantara as a manhaj (religious model) needs to be continuously supported for the future of Indonesian and world civilizations. Islam Nusantara is the face of Islam which is friendly, open, inclusive, and capable to be a solution of nation and world's problems. It is the dynamic and friendly Islam living in a diverse culture, subculture, and religions. Islam is not only suitable for people in Nusantara (Indonesia), but also deserves to be the color of Nusantara's culture to embody its accommodating nature, rahmatanlil 'alamin. ${ }^{2}$

Islam Nusantara is Islam with unique characteristics a la Indonesia; a combination of theological values and local traditions, cultures, and customs in Indonesia. The characters of Islam Nusantara reflect local wisdoms in Nusantara that go hand-in-hand with Islamic teachings. Additionally, it intensifies Islamic teachings with local customs all over Indonesia.

The face of Islam Nusantara needs to be promoted by Indonesian Muslims to the world. The world needs to know that Islam is not only in hands of Middle-Eastern and African. Grand Syaikh al-Azhar through his delegation to PengurusBesarNahdlatul Ulama (PBNU/The Central Board of Nahdlatul Ulama), Dr Mun'imFuad, states his support to Islam Nusantara to spread globally. He asserts that Islam Nusantara is a complete form of Islam which is shaped by intercultural dialogues from grand civilizations, like, Persia, Turkey, India, Siamese China, etc. ${ }^{3}$

The consequence of Islam Nusantara discourse adapted from Nusantara's scholars undoubtedly generates figh discussions. There are many Nusantara's scholars wrote figh books, such as, Mir'atutTulab fi Tasyi' al Ma'rifah al Ahkam As-Syar'iyah li al-Malaik al-Wahab by Abdur Rauf AlSinkili, Sabil al-Muhtadin by Muhammad Arsyad al-Banjari, Sirat al-

${ }^{1}$ Nurcholish Madjid, Islam Keindonesiaan dan Modernisasi (Jakarta: Mizan Pustaka, 2009).

2Syamsudin Arif, Islam Nusantara (Jakarta: Historiografi dan Metodologi, 2000).

3 "Apa itu Islam Nusantara," diakses 12 September 2019, http://www.muslimedianews.com/2015/04/. 
Mustaqim by NuruddinAr-Raniri, Sullam al-Munâjah by Nawawi, Bughyah al-Thullab by Daud al-Fatani, Irsyad al-Ikhwan fi Bayan HukmiSyurb alQahwahwa ad-Dukhan by Syeh Ihsan Jampes, Al-Majmu'at Al-Syari'ah AlKafiyah Li Al-Awwam by SyeikhSolehDarat, An-NafahatSyarah Al-Waraqat by Ahmad Khatib Sambas, Hasyiyah al-Turmusi by Syeikh Mahfud Termas, ZiyadahTa'liqat by Hasyim Asy'ari, etc. ${ }^{4}$

In current context, fighconcepts and paradigms developed by the Nusantara's scholarsare important to discuss since there are many local wisdoms in those concepts and paradigms. It will result in solutions which benefit to the society and in order to formulate a contextual and functional Islamic law that regulates Muslims' religious life. ${ }^{5}$

This study discusses the figh concepts of SyeikhArsyad al-Banjari in his book entitled SabilalMuhtadin. This book introduces figh in the perspective of Nusantara's society, especially the Banjarese society. Al-Banjari was mainly relied on "custom is law" (al-adatumuhakkamah) and "generating benefits or mashlahah and declining damage" (jalb al-mashalihwadar' almafasid) in his ijtihad (independent reasoning).

\section{B. The Biography of SyeikhMuhammad Arsyad al-Banjari}

SyeikhMuhammad Arsyad al-Banjari was born in Lok Gabang, 17 March 1710 and passed away at 3 October 1812, in the age of $102 .{ }^{6} \mathrm{He}$ is a figh scholar from Syafi'i school who lived in Martapura, Banjar Sultanate, South Borneo. He received a posthumous title Datu Kelampaian. He wrote SabilalMuhtadin which becomes a reference for many Muslims in SouthEast Asia.

4 Additionally, "Nusantara" becomes an important discussion not only as a geographic concept, but also as a philosophical concept. It also becomes a perspective, mindset, values, and standpoint in dealing with various cultures. Promoting Islam Nusantara movement is mainly based on Islamic values and norms spread in Indonesian archipelago. It is not built as financial-based movement which is commonly found in institutions and political actors that look for power. Khabibi Muhammad Luthfi, "Islam Nusantara: Relasi Islam dan Budaya Lokal," LP2M IAIN Surakarta Vol. 1, Nomor 1, Januari-Juni 2016 (t.t.).

5 "Acceptance and renewal of local culture by the Quran becomes theological arguments for Islamic scholars, especially among fuqaha (fiqh experts). Thus, Islam does not ruin or challenge the existing traditions. In contrary, Islam comes to enrich and makes traditions and cultures to get similar to Islam gradually (tadriii). Quran's universal values, especially on jurisprudence, are translated into social reality faced by the fuqaha. In this case, ijtihad appears as icon of Islamic jurisprudence dynamic development.," t.t.

${ }^{6}$ Abu Daudi, Muhammad Arsyad Al Banjari (Martapura: Dalam Pagar, 2003). 
Al-Banjari raised in a devoted Muslim family. His father is 'Abdullah and his mother is Aminah. According to Abdurrahman Siddiq, a mufti (religious expert) of Indragiri kingdom, al-Banjari is the descendant of Alawiyyin from Sultan Abdurrasyid Mindanao. ${ }^{7}$ His line of ancestors is Maulana Muhammad Arsyad Al Banjari bin Abdullah bin Tuan Penghulu Abu Bakar bin Sultan Abdurrasyid Mindanao bin Abdullah bin Abu Bakar Al Hindi bin Ahmad Ash Shalaibiyyah bin Husein bin Abdullah bin Syaikh bin Abdullah Al Idrus Al Akbar (the ancestor of Al Aidrus family) bin Abu Bakar As Sakran bin Abdurrahman As Saqaf bin Muhammad Maula Dawilah bin Ali Maula Ad Dark bin Alwi Al Ghoyyur bin Muhammad Al Faqih Muqaddam bin Ali Faqih Nuruddin bin Muhammad ShahibMirbathbin Ali KhaliqulQassam bin Alwi bin Muhammad Maula Shama'ah bin Alawi Abi Sadah bin Ubaidillah bin Imam Ahmad Al Muhajir bin Imam Isa Ar Rumi bin Al Imam Muhammad An Naqib bin Al Imam Ali Uraidhy bin Al Imam Ja'far As Shadiq bin Al Imam Muhammad Al Baqir bin Al Imam Ali Zainal Abidin bin Al Imam SayyidinaHusein bin Al Imam Amirul Mu'mi- nin Ali KaramallahwajhahwaSayyidah Fatimah Az Zahra bintiRasulullah SAW. ${ }^{8}$

Al-Banjari ${ }^{9}$ studied in the sultanate academy up to his 30s. He was arranged to marry Queen Aminah, the daughter of Prince Taha who was Sultan's cousin. Aminah was a devoted and loyal wife to al-Banjari. ${ }^{10}$ When Aminah was pregnant their first child, al-Banjari stated that he wanted to study Islam in Makkah. Although they were in early years of their marriage, Aminah let al-Banjari went to study in the Holy Land.Al-Banjari joined three students from Nusantara who already lived in Makkah, namely, Syeikh 'Abd al-Samad al-Falimbani from Palembang, Syeikh' Abd al-Wahab Bugis from Celebes, and Syeikh'Abd al-Rahman Masri from Betawi-Java. These four students are known as the Four Colleagues of Java. ${ }^{11}$ SyeikhMuhammad Arsyadwas closely associated to these fellow

7 "King of Tidung or Tarakan kingdom from South-East Dinasty namely Sultan Abdurrasid-the descendant of King of Sulu sultanate," t.t.

${ }^{8}$ M.S. Kadir, Shaikh Muhammad Arshad al-Banjari Pelopor Da'wah Islam di Kalimantan Selatan, (Mimbar Ulama, 1976), 69.

${ }^{9}$ Bambang Subiyakto, "Syekh Muhammad Arsyad Al-Banjari: Upaya dan Ajaran Nilai-Nilai Karakter dalam Pendidikan Ilmu Pengetahuan Sosial" (Universitas Pendidikan Indonesia, 2015).

10Sudrajat, Ulama pejuang dan ulama petualang: belajar kearifan dari Negeri Atas Angin. Erlangga, 2006, 77.

${ }^{11}$ Azyumardi Azra, Jaringan Ulama Timur Tengah dan Kepulauan Nusantara Abad XVII dan XVIII, (Bandung, Mizan, 1998), 253. 
students. ${ }^{12}$ SyeikhArsyad al-Banjari also studied in Middle East for quite long period of time. ${ }^{13}$

In the Holy Land, al-Banjari studied to famous teachers, such as, Syeikh'Athaillah bin Ahmad al-Mishry, al-Faqih SyeikhMuhammad bin Sulaiman al-Kurdi, and al- 'ArifBillahSyeikhMuhammad bin Abdul Karim al-Samman al-Hasani al-Madani. The last name is al-Banjari's teacher on tasawuf (Sufism or spiritual contemplation) in which under his supervision, al-Banjari conducted suluk(mysticism) andkhalwat(seclusion) to reach the khalifah (caliphs) position.

In addition, al-Banjari also learnt to other teachers, such as, SyeikhAhmad bin Abdul Mun'im ad Damanhuri, SyeikhMuhammad Murtadha bin Muhammad azZabidi, SyeikhHasan bin Ahmad al Yamani, SyeikhSalm bin Abdullah al Basri, SyeikhShiddiq bin Umar Khan, SyeikhAbdullah bin Hijazi asySyarqawy, SyeikhAbdurrahman bin Abdul Aziz al Maghrabi, SyeikhAbdurrahamn bin Sulaiman al Ahdal, SyeikhAbdurrahman bin Abdul Mubin al Fathani, SyeikhAbdul Gani bin Muhammad Hilal, SyeikhAbis as Sandi, SyeikhAbdul Wahab at Thantawy, SyeikhAbdullah Mirghani, SyeikhMuhammad bin Ahmad al Jauhari, and SyeikhMuhammad Zain bin Faqih Jalaludin Aceh.

After around 35 years studying in both Makkah and Medina, al-Banjari returned to Banjar and soon became a charismatic and respected ulama (Islamic scholar). He played a central role in building new ulama circle in Borneo. ${ }^{14}$ Syeikh Muhammad Arsyad al-Banjari was the key in introducing new religious values in South Borneo.15 During Ramadan 1186 Hijriah (Islamic calendar system) or 1772 A.D., Muhammad Arsyad al-Banjari returned to his homeland, Martapura, the capital of Banjar kingdom. However, Sultan Tahlilullah, the leader who had long supported him, had passed away and replaced by Sultan Tahmidullah II bin Sultan Tamjidullah I, Sultan Tahlilullah's grandson. It was Sultan Tahlilullah who gave a lot of attention to the development of Islam in Banjar kingdom.

12 "Muhammad Arsyad al-Banjari Sang Matahari Agama dari Kalimantan," 18 Juli 2013, Republika.

${ }^{13}$ Fathullah Munadi, "Mushaf Qiraat Syekh Muhammad Arsyad Al-Banjari Dalam Sejaran Qiraat Nusantra"," Al-Banjari: Jurnal Ilmiah Ilmu-Ilmu Keislaman, 9, no. 1 (2010): 61.

${ }^{14}$ Rahmadi, "Jaringan Intelektual Ulama Keturunan Syekh Muhammad Arsyad Ak-Banjari," Al-Banjari: Jurnal Ilmiah Ilmu-Ilmu KeislamanVol.9, No. 2 (2010): 194.

${ }^{15}$ Husnul Yaqin, "Syakh Muhammad Arsyad Al-Banjari's Thought On Education"," Journal of Indonesian Islam 5, no. 2 (2011): 336. 
Sultan Tahmidullah II welcomed al-Banjari's return with a festive celebration. Al-Banjariwas merrily welcomed by the Banjar people and named as "The Sun of Religion" that would enlighten the whole kingdom. After his return, al-Banjarifully devoted his time to teach Islamic teachings. He taught his relatives, kingdom's family members, and society's members. Sultan Tahmidullah II himself was a student of al-Banjari. In his life, alBanjari had seven wives and 29 children. ${ }^{16}$

\section{Syeikh Muhammad Arsyad al-Banjari's Works}

The most renown book written by Syeikh Muhammad Arsyad alBanjari is SabilalMuhtadin li al-Tafaqquh fi Amriddin (The Path of Selected People to Learn Religion). Al-Banjari also wrote other books which he used for teachings, such as, KitabUshuluddin(book of Twenty Characters) and TuhfaturRaghibin(book of Bad Intentions and Deeds).

Al-Banjari also wrote Nuqthah al-Ajlan which discussed women's characters and spouse's rights and obligations. His other book entitled alFara-idh talked about procedure of inheritance. Al-Banjari's personal monograph and his students' notes were made into a book named Kitab Parukunan. This book talked about the requirements of syahadat (confession of faith), shalat (prayers), thaharah (cleanliness), and siyam (fasting). On tasawuf, al-Banjari wrote Kanz al-Ma'rifah.

Al-Banjari's concept on fiqh was written down in his monumental book, Sabil al Muhtadin li al-Tafaqquhi fi Amri al-Din. The book's title was then adapted by the government of South Borneo Province to name a masjid in Banjarmasin, Masjid Raya SabilalMuhtadin. For Banjarese, SabilalMuhtadinis a mark or al-Banjari's expertise and piousness in fiqh, especially in Shafi'i school.

In SabilalMuhtadin, al-Banjari discussed religious practices and some other religious issues, like, aqeeqah (sacrificing an animal to mark the occasion of a child's birth), qurban (slaughtering sacrifice animals), and types of hunted and sacrificed animals. In details, this book consists of two volumes. The first volume has 252 pages discussing about taharah (cleanliness) to requirements for shalat (prayers). The second volume has 272 pages discussing sujud sahwi (prostration of forgetfulness) to halal (allowed to consumed) and haram (prohibited to consumed) food.

SabilalMuhtadin illustrated a slight difference in discussing fiqh compared to other works in the era. The difference lied in local wisdoms of Banjarese which was accommodated in SabilalMuhtadin. One of the

${ }^{16}$ Muslich Shabir, Pemikiran Syekh Muhammad Arsyad al-Banjari tentang Zakat: Suntingan Teks dan Analisis Intertekstual (Jakarta: Penerbit Nuansa Aulia, 2005), 20. 
examples was on inheritance dispute. Al-Banjariaccommodated local culture in which women received significant amount; thus, gender equality values met religious and cultural dialectics.

Al-Banjari's innovative figh concepts required a long process. There were many important events and strategic reasonings which gave foundations to his concepts. More importantly, Banjarese's interests on those strategic issues were closely related to sociocultural condition of the society itself that should go hand-in-hand with Islamic legal basis. ${ }^{17}$

\section{The Fiqh Concepts of Syeikh Muhammad Arsyad al-Banjari in Sabil al Muhtadin}

\section{Zakat Receivers}

Banjarese lived in poverty at that time. Things got worse by the increasing number of elderly in the society. Al-Banjari wished to solve this problem by introducing the concept of improving society's welfare. One of the key solutions was zakat (obligatory alms). Al-Banjari mentioned that zakat was part of the Five Pillars; thus, one who refused to do it can be considered rejecting Islam. ${ }^{18}$ People who refused to pay zakat could be confronted and his/her portion of zakat could be taken by force, even by war. The target of this solution was wealthy people, including the kingdom's officials.

Al-Banjari, quoted Waqi' bin Jarrah, believed that zakat was similar to sujud sahwi; it complemented deficiencies in fasting in a way sujud sahwi complemented deficiencies in prayers. Al-Banjari's concept on zakat was written down in a section of SabilalMuhtadin. Additionally, Al-Banjari determined that fakir (people who lived solely from alms) and miskin (people who lived in poverty) who deserved to get zakat were widows, orphans, elderly people, and children who needed proper sustenance, yet they did not own any wealth or proper occupation. ${ }^{19}$

Al-Banjari pointed out that people who had permanent housing but unable to fulfil their basic needs, like food and clothing, were also fakir. People who learnt Islam also considered fakir since they could not work at that moment. Syeikh Muhammad Arsyad al-Banjari was an expert of Syafi'i

${ }^{17 F a u z i a h, ~ " K o n s e p ~ U ' r f ~ d a l a m ~ P a n d a n g a n ~ U l a m a ~ U s h u l ~ F i q i h: ~ T e l a a h ~}$ Historis"," Jurnal Nurani 14, no. 2 (Desember 2004): 17.

${ }^{18}$ Anita Arianti, "Gerakan Pemurnian Islam Syekh Muhammad Arsyad AlBanjari di Kalimantan Selatan" 14, no. 3 (2010).

${ }^{19}$ Shaikh Muhammad Arshad al-Banjari, Kitab Sabilal Muhtadin, Jilid 2, terj. Asywadie Syukur, (Surabaya: Bina Ilmu, 2003), 808. 
school, especially on the application offatwa (religious leader's official statement or order) made by Syafi'iyyah scholars. ${ }^{20}$

Miskin are people who deserved zakat. Although they owned wealth or had decent occupations, they could not sufficiently provide for themselves or other people under their care (i.e. wife or children). For instance, a family required 10 dirhams to sufficiently fulfil its needs for one day. When there was a family that could only provide 7 or 8 dirhams in one day, it could be classified as miskin. When members of the family (husband/wife, grandparents, children, grandchildren) who lived in poverty and they were sufficiently supported by other family member, they could not be classified as either fakir or miskin. The term applied to wife who were insufficiently supported by her husband. Nevertheless, she could only receive zakat to cover the insufficiency. Al-Banjari explained in details about the way fakirandmiskin in the kingdom received zakat. He asserted that zakat in Banjar kingdom should sustainably be given to the fakirandmiskin. ${ }^{21}$

Al-Banjari mentioned that fakir and miskin who were unable to work were eligible to receive zakat to support their life. If the common living rate was 60 years and the zakat's beneficiary was 40 years old, he/she could receive zakat that sustained his/her life for the next 20 years.Zakat in this case was not in the form of money; it could be anything that had productive values in it. This regulation was eligible for people with aforementioned condition.

\section{Floated Lavatory (Istinja')}

Al-Banjari mentioned about defecating in SabilalMuhtadin page 48:22(It is acceptable to defecate in the direction that neither face nor back the Qibla. When there is no proper place to defecate, there need to be proper walls in between him/her with the Qibla direction. It should be two-thirds cubits or more in height and three cubits or less in width. When all of the aforementioned requirements cannot be fulfilled, the person is considered conducting khilafawla (violating the virtue). When there is no other choice but using lavatory that either face or back the Qibla, it is not considered makruh (detested) or khilafawla. It is (half) makruh and haram (forbidden) for a person to defecate in a lavatory that face or back the Qibla with

${ }^{20}$ Mohd Azhan Zakaria, "Kitab Zakat Dalam Kitab Sabil Al-Muhtadin Karya Syekh Muhammad Arsyad Al-Banjari Anotasi dan Analisis / Mohd Azhan Zakaria"'" (University of Malaya, 2015).

${ }^{21}$ Kitab Sabilal Muhtadin, Jilid 2, terj. Asywadie Syukur, 89.

${ }^{22}$ Muhammad Arsyad Al-Banjari, Sabil Al-Muhtadin, Juz I, 48. 
improperly measured walls or even no walls in between him/her with the Qibla direction. As the requirements are mentioned in a hadith by Bukhari and Muslim, Prophet Muhammad (PBUH) prohibited his followers to face or back the Qibla when they urinate or defecate).

For Banjarese who lived by the riverbank, it was acceptable to have lavatory floated in a raft or boat. Al-Banjari did not strictly aim to floated lavatory in his book. He rather discussed acceptable measurement of a proper lavatory. It should be two-thirds cubits or more in height and three cubits or less in width. The Banjarese used to build wider lavatory than the size proposed by Al-Banjari. As raft or boat kept changing direction due to water flow, Al-Banjari mentioned that it was acceptable that people defecated facing or backing the Qibla direction. Hence, this concept shows the relation of figh with local wisdoms of Banjar society. ${ }^{23}$

The aforementioned illustration indicates al-Banjari'sijtihad on using floated lavatory. He wished that the lavatory equipped with walls; thus, it is classified as takhshiniyat (tertiary) needs.

\section{Corpse Burial in a Coffin (Tabala)}

Al-Banjari wrote extensively on corpse treatment in a chapter entitled Janaiz. Here, he explained on the definition of corpse, suggestion on visiting sick person, proper treatment upon sick person, guidance on dealing with sakaratulmaut (agony of death), guidance ontakziah (commiseration), guidance on before and after bathing the corpse, and guidance on covering and burying the corpse. One of the problems related to local wisdom on corpse treatment is corpse burial with tabala method. ${ }^{24}$ Al-Banjari wrote ${ }^{25}$ (It is considered makruh(detested) and even bid'ah(heresy) to bury a corpse in tabala since it is weak on wet or fragile land. Also at the time there is female corpse buried without the presence of her mahram (spouse, male relatives). Also, there is fear that the corpse will be dug out by wild animals).

As agreed by Islamic scholars, it is makruh(detested) to bury a corpse in coffin. It is even considered bid'ah (heresy). First exception is taken when the grave is on a wet or watery land. Second is the presence of wild animals that may dig out the grave, even though the corpse has been covered and placed in packed soil. Finally, a female corpse who is buried without the

${ }^{23}$ Muhammad Arsyad Al-Banjari, Sabil Al-Muhtadin, Juz II, 83.

24 "In swamp area, before the corpse is buried, it is placed in a coffin called tabala in Bajarese tradition. Thus, the size of the grave will be smaller than graves in higher land or non-swamp area (normally 1.5 fathom and 3 cubits)," t.t.

${ }^{25}$ Muhammad Arsyad Al-Banjari, Sabil Al-Muhtadin, Juz II, 83. 
presence of her mahram (spouse, male relatives). Here, using coffin considered generates greater benefits. Therefore, it is no longer makruh.

In general, Banjarmasin is located in lowland; therefore, its land is almost in the same level or even lower than the water area. In this case, burying corpse using tabala is considered common among Banjarese as it respects the corpse itself and keeps it in good condition. Thus, corpse burial using tabala is part of local wisdom in Banjarese society due to the nature of its land. However, the burial can be done without tabala in areas with more solid soil. ${ }^{26}$

It can be deduced that Syeikh Muhammad Arsyad al-Banjari's statement on tabala is mainly based on a figh principle "along with difficulty, there is ease" (al-masyaqqahtajlib al-taisir). ${ }^{27}$ Corpse burial without coffin may cause trouble to the grieving family; hence, tabala is allowed to lighten the burden and keeps the mutual benefits.

\section{Building Construction on Graveyard}

Al-Banjari wrote a section in SabilalMuhtadindiscussing about building construction on graveyard 28 (It is lawfully prohibited to build anything, like, dome, house, or fence on a piece of land that has been given (waqf) as graveyard. All Muslims should forbid anything built on it and removed anything that has been placed on it).

Banjarese has a tradition of corpse burial in a land called maqbarah (Muslims' graveyard). It belongs to a group of people who attend the same religious gathering group. The graveyard is communally bought and made into waqf land. However, Banjarese usually builds dome, house, or fence over the graveyard and it has been done for centuries. Al-Banjari asserted that building any construction over graveyard is prohibited. Moreover, Muslims should forbid anything built on it and removed anything that had been placed on it. Even though al-Banjari banned any construction building over a graveyard, he allowed personal land to be made into graveyard.

This statement is classified as dhruriyat(primary) in spreading the Islamic teachings. Graveyarddiscussed in this section is one that has been given as waqf. The graveyard which has building on it will narrow down the waqf land itself. On the other hand, the number of people who require graveyard keeps increasing. Islamic teachings command corpse burial and

26 "Upacara kematian pada Masyarakat Banjar," t.t., http://uunhalimah.blogspot.co.id/2008/06.

${ }^{27}$ Tajuddin al-Subky, Al-Asybah wa al-Nazhair (Beirut: Dar al-Kutub alIlmiyyah, 1991), 10.

${ }^{28}$ Muhammad Arsyad Al-Banjari, Sabil Al-Muhtadin, Juz II, 85. 
construction building on graveyard will contradict to the teachings. When the graveyard lies in personal-owned land, al-Banjari did not forbid any building construction in it. He pointed out on the habit of Banjarese who built house or fence over maqbarahthat had become waqf land. ${ }^{29}$

\section{Providing Food for Mourners}

Al-Banjari wrote a section in SabilalMuhtadindiscussing about providing food for mourners, 30 (It is sunnah (allowed)for funeral goersto bring food to the grieving family that will be sufficient for the following day or even the following night. It ismakruh (detested), even bid'ah(heresy) for the grieving family to provide food from its crops to all funeral goers, as custom suggested. Also, it is makruh and even bid'ahfor those who suggested it (to provide food). Finally, it is haram (prohibited) for the grieving family to provide food by crying or wailing as it will lead to maksiat(sin).

It was a custom among Banjarese; after completing a funeral, they would be asked to visit the house of the grieving family to eat the food that the family prepared. ${ }^{31}$ This custom was then reviewed by al-Banjari by giving the rules; it is sunnah (allowed) for funeral goersto bring food to the grieving family since the family will be busy taking care of the funeral process and it may not have the time to cook. Thus, the grieving family members will have enough strength (dhaif) by consuming the food. It ismakruhfor the grieving family to provide to all funeral goers. It is haram for the grieving family to provide food by crying or wailing.

\section{E. Ijtihad Model of Syeikh Muhammad Arsyad al-Banjari}

The term ijtihad in its basic form comes from fi'ilmâditsulatsimujarrad, jahada-yajhadu, jahdan, not juhd, which means an effort or endeavor. ${ }^{32}$ Ijtihad, etymologically, means power and ability mobilization from tough and problematic activities (badzl al-wus'iwa al-majhîd). ${ }^{33}$ The power and ability can generally be applied in physical-material, mental-spiritual, and intellectual power. Terminologically, ijtihad is attachedto aforementioned elements. Since various scientific activities rely mainly on intellectual activities, ijtihad is closely defined as intellectual capacity mobilization to solve problems faced by individual or society. In ushulfigh, ijtihad is

\footnotetext{
${ }^{29} \mathrm{Ibid}$

30Ibid, 87

31 "Upacara kematian pada Masyarakat Banjar."

32 "Upacara kematian pada Masyarakat Banjar."

33Ibn Manzhûr al-Ifriqi, Lisân al- 'Arab (Beirut: Dâr al-Shâdir, t.t.), 133-35.
} 
terminologically defined as an effort to formulate sharia law from specific sharia sources (badzl al-juhd li wushûl al-hukm al-syar'i min dalîl al-tafsîl min adillah al-syar'iyyah). ${ }^{34}$

Al-Syaukani defines ijtihad as "using personal capacity to achieve practical Islamic law using istinbâth(in-depth examination) method (badzl al-wus'ifinaylhukmsyar'i bi tharîq al-istinbâth)." 35 This definition seems identical to other definitions mentioned by ushulfigh scholars in general, such as, al-Ghazâliand al-Amidi. According to al-Ghazâli, ijtihad is "greatly using personal capacity to achieve comprehension on Islamic law (badzl almujtahid wus'ahufithalab al-'ilm bi ahkâm al-syari'ah)." 36 Similar definition is also offered by al-Amidi who states that ijtihad is using personal capacity to achieve comprehension on Islamic law with zhanni (vague meaning) until one is no longer able to interpret the law (istifrâgh al-wus'ifithalab alzhann bi syai'inmin al-ahkâm al-syar'iyyah 'alâwajhyahussumin al-nafs al-'ajz 'an al-mazîlfih). ${ }^{37}$

Additionally, al-Syirazi asserts that ijtihad is fully using personal capacity to achieve comprehension or new discovery on Islamic law (ijtihâdhuwaistifrâgh al-wus'iwa badzlul al-majhûdfithalab al-hukm alsyar'i). ${ }^{38}$ Muhammad Khudhari Bik defines ijtihad as an effort made by fiqh

34 Coming from the same root word is the words jihâd and mujâhadah. These three terms chiefly mean using entire effort and capacity to maintain Islam in various fields. Ijtihad means effort that one has made to fulfill requirements that suit his/her rational in finding law that does not clearly mention in Quran and Hadith. One that conducts such efforts is known as mujtahid. Jihad points out on earnest effort made with physical and material resources to maintain Islam in numerous ways and forms. One that conducts such efforts is known as mujahid. Mujâhadahpoints out on earnest efforts made to fight against personal passion and desire, so that he/she will conduct God's orders and avoid God's restrains. One that conducts such efforts is known as salik or murid. Abd al-Wahab Khallaf, 'Ilm al-Ushul al Figh (Kairo: Dar al-Qalam, 1978); Louis Malouf, al-Munjid fi al-Lughah (Beirut: Dâr al-Masyriq, 1986); Muhammad Ibn 'Ali al-Syawkâni, Irsyâd alFukhûlilâTahqî̀ al-Haqq Min 'Ilm al-Ushûl (Surabaya: Maktab Sa' adI bnNabhân, t.t.).

${ }^{35}$ Muhammad ibn 'Ali al-Syawkâni, Irsyâd al-Fukhûl ilâ Tahqîq al-Haqq min 'Ilm al-Ushûl (Beirut: Dâr al-Fikr, t.t.), 250.

${ }^{36}$ Abû Hâmid Muhammad al-Ghazâli, al-Mustashfâ min 'Ilm al-Ushûl, Juz II ((Beirut: Dâr al-Fikr, t.t.), 350-54.

${ }^{37}$ Saif al-Dîn Abû al-Hasan 'Ali ibn Abî 'Ali ibn Muhammad al-AmidiSaif alDîn Abû al-Hasan 'Ali ibn Abî 'Ali ibn Muhammad al-Amidi, al-Ihkâm, Juz IV, t.t., 309; Abû Ishâq al-Syîrazi, al-Luma' fì Ushûl al-Figh (Kairo: Muhmmad 'Ali Shabîh, 1999).

${ }^{38}$ Al-Luma' Fî Ushûl al-Figh, 75; Amir al-Hajj, Al-Taqrîr Wa al-Tahrîr Fî 'Ilm alUshûl, Juz III (Beirut: Dâr al-Fikr, 1996), Juz III 388. 
scholar or mujtahid to achieve comprehension on Islamic law. ${ }^{39}$ According to Fazlur Rahman, ijtihad refers to the striving of the jurists to the point of mental exhaustion to derive principle and rules of law from evidence found in the sacred texts of sources. ${ }^{40}$

Based on aforementioned definitions, ijtihad in Islamic law can be seen as a determined intellectual effort to achieve legal solution on a problem in zhanni (vague in meaning) level. ${ }^{41}$ Hence, in conducting ijtihad, there are some requirements. First, mujtahid uses his maximum effort. Second, the effort is mainly aimed at searching for Islamic law with zhannicondition. Finally, the search on zhanni should be in accordance with Quran and hadith. 42

Al-Banjari's ijtihad in SabilalMuhtadin to the fiqh of Banjarese's problems uses at least three patterns, namely bayani, qiyasi, and istishlahi. First of all, ijtihad bayâniis a legal reasoning method that is mainly based on semantic studies. This method is also called literal method (tharîgahlafzhiyyah) for it aims to sharia texts, like, Quran and hadith. It shows how the words are used to explain particular figh law. Thus, the basis of this method is analyzing words in Quran and hadith that relies on Arabic grammar. ${ }^{43}$

In discussing thaharah, for instance,al-Banjari studied it through bayânimethod. He explained this obligation based on descriptions provided in Quran and hadith. He stated that thaharah means an act to clean the body from hadas (dirty, unclean) and najis (impurities, dirt). It can be done through wudhu (ablution), mandi janabah (full ablution), tayamum, (dry

${ }^{39}$ Muhammad Khudari Bik, Ushûl al-Fiqh (Beirut: Dar al-Fikr, 1981), 367.

40Fazlur Rahman, Post Formative Developments in Islam (Karachi: Islamic Studies, 1962), 12.

${ }^{41}$ Muhammad Ibn 'Ali al-Syawkâni, Irsyâd al-FukhûlilâTahqîq al-Haqq Min 'Ilm al-Ushûl; Muhammad Abûzahrah dan al-Imâm Zayd, Hayâtuhwa 'AshruhwaArâ'uhwaFiqhuh ((Kairo: Dâr al-Fikr al- 'Arabi, 1974); Khabibi Muhammad Luthfi, "Islam Nusantara: Relasi Islam dan BudayaLokal," IAIN Surakarta 1, Number 1, January - June 2016, . (t.t.): 3.

42 "From the aforementioned explanation, ijtihad requires texts from the Quran and hadith in the form of nashshs which means words with definite legal provisions and there is no interpretation; and then zhahir which means words with vague meaning and there is possibility of having interpretation. In addition, we need to identify texts from the Quran and hadith which is manthûq (explicit) and mafhûm (implicit). After that, mujtahid needs to pay attention to Prophet Muhammad's behavior and provision, followed by ijmâ' and qiyâs.," t.t.

43Wahbah Zhaily, Al-Figh al-Islâmy wa Adillatuhu (Beirut): Dâr Al-Fikr, 1997), 137. 
ablution), or removing the dirt or najis. ${ }^{44}$ In addition, keeping cleanliness is a compulsory for Muslims, as it is the command of Allah and Prophet Muhammad, as mentioned in Al Baqarah verse 222 “... Indeed, Allah loves those who are constantly repentant and loves those who purify themselves." Prophet Muhammad (PBUH) also stated that "Cleanliness is next to godliness." 45

The transcription of the commands illustrates ijtihad on cleanliness that consists of thaharahhakiki and thaharahhukmi. Thaharahhakikimeans being clean in physical, attire, and place for prayer.Thaharahhukmimeans being clean from actions that cause a person unable to conduct prayers. It can be done by having wudhu or mandi janabah. This type of ijtihad belongs to ijtihadbayâni. Al-Banjari used ijtihadbayâni in discussing figh law in SabilalMuhtadin.

Secondly, ijtihadqiyâsi(analogy) is an effort to describe Islamic law that is not explained in nash (legal texts) by giving analogy through similar law cases or stories provided in nash. In its practice, this method is used to supplement explanation made through bayâni method. This method can strengthen the argument or provide different conclusion to make the reasoning much more logical and understandable. ${ }^{46}$

One of the ijtihad qiyâsithat al-Banjari practiced is in his statement on constraints. He illustrated constraints law with partnership law (shirkat al'abdan). Fiqh scholars defined shirkah (partnership) as an agreement (akad) between two people who work together in capital and profits. ${ }^{47}$ Meanwhile, shirkat al- 'abdan is an agreement between two people in accepting an assignment with agreed wage provisions. ${ }^{48}$

44Muhammad Arsyad Al-Banjari, Sabil Al-Muhtadin, Juz II, 83.

45Imam Muslim, Shahih Muslim (Beirut: Dar al-Fikr, 1998).

${ }^{46}$ Abdul Wahhab Khallâf, Mashâdir Tasyri' Al-Islâmy Fimâ Lâ Nashsha Fih (Kuwait: Dar Al- Qalam, 1979), 19; Ahmad Azhar Basyir, Pokok-Pokok Persoalan Filsafat Hukum Islam (Yogyakarta: UII Press, 2000), 20.

47Sayyid Sabiq, Fikih Sunnah translation. Nor Hasanuddin, Jilid 4 (Jakarta: Pena Pundi Aksara, 2007), 317.

48 According to Salih bin Fauzan, shirkat al- 'abdan is an agreement between two or more people who work together for their efforts. Therefore, as each member of the alliance or trust contributes to the given job, he/she deserves to get wage for his/her contribution. Types of job in this shirkah (partnership) can be varied. However, these varied assignments mainly head to one type of assignment, service. Service can be in form of personnel, profession, etc. Some examples of the job are seamstress, color maker, blacksmith, firewood collectors, artisan, etc. Salih bin Fauzan al-Fauzan, Ringkasan Fikih Lengkap, translated. Asmuni, (Jakarta: PT. Darul Falah, 2005). 
Related to constraints law, a sum of wealth that a Banjarese husband and his wife got was a form of cooperation to achieve mutual profits. The husband who worked as fisherman or farmer and his wife who made crafts and trade were equally share the cooperation principle. Therefore, alBanjari asserted that wife deserved half of the constraints and vice versa.

On the idea of constraints law, al-Banjari mainly relied on common law that Banjarese had, namely AdatBasuluh ${ }^{49}$ atauAdatBadamai.50AdatBadamai is one of Banjarese tradition in settling a dispute by having discussion. AdatBadamai is also a way to avoid dispute that may ruin the common law. Al-Banjari mainly agreed to AdatBadamai since this common law was compatible to Islamic law and maslahah (common good) principles. ${ }^{5152}$

Ijtihad qiyâsi that al-Banjari used in dealing with constraints was a breakthrough and rarely found in common references in family or Islamic law, especially ones that discussed inheritance. His statement is still widely accepted by Banjarese since it has justice and reflects fairness and equality. 53

Thirdly, ijtihad istishlâhiis a legal reasoning method that is mainly used common verses to create universal principles to protect and achieve maslahah. Basically, the essence of sharia implementation (tasyri') is to reach maslahah. These principles are implemented in three levels, namely, dlarûriyah (primary needs), hâjizyyah(secondary needs), andtahsiniyah(tertiary needs). Therefore, problems in society deduced by the aforementioned principles. ${ }^{54}$

Al-Banjari used this final method in dealing with legal reasoning. For instance, al-Banjari allowed corpse burial with tabala which commonly used to benefit the corpse, the grieving family, and the burial caretaker. ${ }^{55}$ Constraints law basically serves maslahahas well, both husband and wife. As well as on construction building on maqbarah land; it is considered

49 "Basuluh", comes from Arabic vocabulatyal-sulhu, which means peace.," t.t.

${ }^{50}$ Ahmadi Hasan, Adat Badamai: Interaksi Hukum Islam dengan Hukum Adat Pada Masyarakat Banjar, (Banjarmasin: Antasari Press, 2007), 50.

51200.

52220 .

53220 .

${ }^{54}$ Abdul Wahhab Khallâf, Ilmu Ushul Al-Fikih (Beirut: Dar Al-kutub al-Ilmiyah, 2007), 160-64; Muhammad Khalid Mas'ud, Shatibi's of Islamic Law (Islamabad: Islamic Research Institute, 1995), 154; Amir Mu'allim dan Yusdani, Konfigurasi Pemikiran Hukum Islam (Yordania: UII Press, 2005), 55-56; Muhammad Abid alJâbiri, al-Dîn wa al-Daulah wa al-Tatbîq al-Syarî'ah (Beirut: Markaz Dirasah alWahdah al-'Arabiyah, 1996), 190.

${ }^{55}$ Muhammad Arsyad Al-Banjari, Sabil Al-Muhtadin, Juz II, 83. 
crucial as the land will be used by many people who wants to bury their passing relatives.

\section{F. Analysis on the Fiqh Concept of Syeikh Muhammad Arsyad al- Banjari}

\section{Syafi'iyyah oriented}

In the scientific genealogy perspective, al-Banjari's statements or decisions reflected his preference on Syafi'i school. ${ }^{56}$ He understood and immersed in the Syafi'i environment. What he personally mentioned that his figh concepts chiefly sourced from Syafi'i school as mentioned in the preface of SabilalMuhtadin, his monumental book.

However, he did not state it explicitly in his kitab an-nikah (marriage book).In all al-Banjari'sfiqh concepts, it can be identified that the statements refer to Syafi'i school. Al-Banjari'skitab an-nikah has many resemblances to kitab fath al-Qarib which also belongs to Syafi'i school. The resemblances can be found in the structure and content of both books which discuss about various issues on marriage. 57

For instance, by the beginning of the book, al-Banjari discussed marriage law which he considered sunnah (acceptable, allowed) and could also be makruh(reprehensible, detested). He proposed the concepts the same way as kitab taqrib (intermediate book commonly adapted by boarding schools using Syafi'i school). In kitab taqrib, marriage is also considered sunnah as in al-Banjari's concept. Next, similarities also found in the discussion about law on women and ihdad (a waiting period that a woman must observe after the death of her spouse or a divorce and in which she may not remarry) in both fath al-Qariband SabilalMuhtadin. However, in fath al-Qarib, there is an additional discussion on hadlanah (childcare rights). Even though al-Banjari did not mention about hadlanah, he intensely discussed about marriage requirements. These points are probably the emphasis of his discussion. .5

References used by al-Banjari in SabilalMuhtadin are varied. Yet, they were dominated by Syafi'i school's scholars, such as, Sharah al-Minhaj by Sheikh al-Islam Zakariya al-Ansari, Al-Mughni by Sheikh Khatib Sharbini, Al-Tuhfah by Sheikh ibn Hajar al-Haitami, Al-Nihayah by Sheikh Jamal alRamli, Mir'at al-Tullab by Sheikh 'Abd al-Rauf al-Sinkili, Singkel, Sirat alMustaqim by Sheikh Nur al-Din al-Raniri, Aceh. Additionally, al-Banjari

${ }^{56}$ M. Fahimul Fuad, "Nomenklatur Pemikiran Hukum Syaikh Arsyad AlBanjary," Online Jurnal Publications Stai Darussalam Lampung Vol. 2, no. No. 2 (2013): 89.

5790.

5890. 
also cited some other works, such as, Al-Majmu' by Imam al-Nawawi and Ihya' 'Ulum al-Din by Imam al-Ghazali, experts' statements or comments in form of matan (content of the hadith), sharah(explanation or interpretation of the hadith), and others.

\section{Social Changes Dependency}

Human being is a social creature who needs to interact one another. Cross-cultural social interaction among nations in this globalization era will speed up social changes. ${ }^{59}$ The effects of social changes are not only created gap between old and new values, but also created gap between established law and changing social reality. One of the effects of the social changes is an influenceon concept and regulation of Islamic law. 60

Islamic law that is mainly sourced Quran and hadith is a set of rules and regulation comes from the Almighty to regulate various aspects of human beings' lives; yet, both sources have limited range. On the other hand, social changes and social problems will always grow and flourish according to legal certainty. Problem that is never predicted to exist may appear and rapidly spread in this contemporary era. In one hand, Quran has been completely conveyed and hadith will no longer be expanded as Prophet Muhammad (PBUH) has passed away. On the other hand, human beings will face contemporary problems related to Islamic law that may not be recorded in both Quran and hadith. ${ }^{61}$

Dynamic is the characteristic of Islamic law which indicates its capacity to accommodate, respond, and answer new problem which solution is not yet regulated in Quran and hadith as an unavoidable logical consequence of social change. ${ }^{2}$ Social change and law has an interactive relation. It indicates that there is a relation between social change and law change and vice versa. ${ }^{63}$

${ }^{59}$ Wilbert E, Maore, Order and Change: Essay in Comparative Sosiology (New York: John Wiley \& Sons, 1967), 3.

${ }^{60}$ Ghufron A Mas'adi, Pemikiran Fazlur Rahman tentang Metodologi Pembaharuan Hukum Islam; Muhammad Khalid Mas'ud, Filsafat Hukum: Studi Tentang Pemikiran Abu Ishaq al-Syatibi (Bandung: Pustaka, 1999), 1 (Jakarta: Raja Grafindo Persada, 1997).

${ }^{61}$ Fathurrahman Azhari, "Dinamika Perubahan Sosial dan Hukum Islam," Jurnal al-Tahrir Vol. 16., no. No.1 (Mei).

${ }^{62} \mathrm{Ibn}$ Rusyd, Bidayat al-Mijtahid wa Nihayat al-Muqrashid (Indonesia: Dar alKutub al-Arrabiyyah, t.t.), 36.

${ }^{63}$ Munir Fuady, Sosiologi Hukum Kontemporer Interaksi Hukum, Kekuasaan, dan Masyarakat; Lahmuddin Nasution, Pembaharuan Hukum Islam Dalam Mazhab Syafi'i (Bandung: PT. Remaja Rosdakarya, 2001), 254 (Bandung: Citra Aditya, 2007), 61; 
Islamic scholars realize that Islamic law can embrace changes as Islamic law's elasticity theory believed by some law experts, such as, Linant de Ballefonds, majority of mujaddid (reformer), and contemporary fiqh scholars. The flexibility of Islamic law in its practice indicate that Islamic law can adapt to social changes. It is meant to be dynamic and relevant to every era and circumstance. Without the effort to change and reform, Islamic law will face problems in its implementation. ${ }^{64}$

Muhammad Arsyad al-Banjari was fully aware on the meaning of social change and Islamic law dynamic. His opinions in SabilalMuhtadin describe the dynamic and adaptability of Islamic law itself to situation, condition, and causes (illat al-ahkam) among Banjarese. Therefore, figh concepts that he proposed had to meet the society's situation and condition.in the case of floating lavatory, for instance, al-Banjari stated that people can urinate or defecate by facing or backing the Qibla direction as long as they put cover over the lavatory. This statement came up from the habit of Banjarese to defecate in a raft or boat which keeps changing direction due to river flow. ${ }^{65}$ Al-Banjari's opinion on corpse burial with tabala mainly based on the condition of land structure in Banjar which made burial without coffin was impossible due to water content in the soil or land. 66

Al-Banjari's opinion is compatible with a figh principle la yunkarutaghayyur al-ahkam bi taghayyur al-azman (changes in Islamic law is inevitable because of changes in times). ${ }^{67}$ His opinion is also in line with Ibn Qayyim al-Jawziah's opinion which wrote a figh principle taghayyur alfatwa bi taghayyur al-zaman wa al-makanwa al-ahwalwa al-'adah (changes in law opinions happens for changes in time, place, situation/intention, and custom). ${ }^{68}$

Lahmuddin Nasution, Pembaharuan Hukum Islam Dalam Mazhab Syafi'i (Bandung: PT. Remaja Rosdakarya, 2001), 254.

${ }^{64}$ Djazuli, Ilmu Figh Penggalian, Perkembangan dan Penerapan Hukum Islam (Jakarta: Kencana Prenada Media Group, 2005), 72; Musa, Tarikh al-Fiqh al-Islami (Mesir: Dar-al-Kitab al-'Arabi, 1958), 14.

${ }^{65}$ Muhammad Arsyad Al-Banjari, Sabil Al-Muhtadin, Juz II, 83.

${ }^{66}$ Muhammad Arsyad Al-Banjari, Sabil Al-Muhtadin, Juz II, 83, 90.

67Ibn Qayyim al-Jawziyah, I'lam al-Muawaqi'in 'an Rabbi al- 'Alamin (Bairut:

Dar al-Fikr, n.d.), 14

${ }^{68} \mathrm{Ibn}$ Qayyim al-Jawziyah, I'lam al-Muawaqi'in 'an Rabbi al- 'Alamin (Bairut:

Dar al-Fikr, 14), 14. 


\section{Refering to al-AdatuMuhakkamah principle}

Custom in Arabic means specific habits that a person or community have. Al-'adah comes from the word al-'awud(العود)) or al-mu'awadah(المؤدة) which means repeated (التكرار). Hence, an action that is repeatedly done which requires no effort can be classified as custom. ${ }^{69}$

According to figh scholars, custom is a norm attached to a person or community due to its repeated nature and finally accepted as rational and acceptable reality, for instance, individual norms, like, sleeping, eating, drinking, etc. Furthermore, social norm is a general truth that is created, agreed, and applied in a certain community; hence, it becomes a social compulsory that must be communally obeyed.70In addition, muhakkamah means judge's decision in court to resolve a dispute, in which custom can also be a judge's reference in settling the dispute. ${ }^{71}$

Custom is an inseparable part of society's life. Custom is a habit that appears in society. Islam can tolerate custom as long as it does not contradict to Islamic law. Even, Islam makes custom as reference to formulate law as long as it fulfills mandatory requirements. ${ }^{72}$

Muhammad Arsyad al-Banjari understood that custom contributes in shaping Islamic law itself. Custom could strengthen the role of Islamic law in people's lives. Therefore, al-Banjari did not forbid the practice of existing custom, as long as the custom did not contradict to sharia. He believed that the existing custom can be part of Islamic law. This opinion can be found in a chapter of SabilalMuhtadin discussing about constraints. His decision was mainly based on existing customs in Banjar, namely AdatBasuluh or AdatBadamai. These customs applied in order to avoid dispute that might harm social order. Al-Banjari's stance on AdatBasuluh and AdatBadamai

${ }^{69} \mathrm{Abd}$ al-Aziz Azzam, al- Maqasid alShariyyah Fi al Qawaid al-Fiqhiyyah (Kairo: Dar al-Bayan Li al Tibacah Wa al-Nashr, 2001); Tamrin Dahlan, Kaidah-kaidah Hukum Islam (Kulliyah al-Khamsah) (Malang: UIN Maliki Press, 2010), 203.

${ }^{70}$ Maioen Zubair, Formulasi Nalar Figh Telaah Kaidah Figh Konseptual (Surabaya: Khalista, 2005), 274; Usman Muchlis, Kaidah-Kaidah Istinbath Hukum Islam: KaidahKaidah Ushuliyah dan Fighiyah, (Jakarta: PT Raja Grafindo Persada, 2002), 210.

${ }^{71}$ Arfan Abbas, Kaidah-kaidah Fiqh Muamalah dan Aplikasinya dalam Ekonomi Islam dan Perbankan Syariah (Jakarta: Direktorat Pendidikan Tinggi Islam dan Direktorat Jenderal Pendidikan Islam Kementerian Agama RI, 2012), 204; A Dzazuli, Kaidah-Kaidah Fikih: Kaidah-Kaidah Hukum Islam dalam Menyelesaikan Masalah-Masalah yang Praktis, (Jakarta: Kencana, 2007), 86; Jaih Mubarok, Kaidah Figh: Sejarah dan Kaidah-Kaidah Asasi (Jakarta: PT Raja Grafindo Persada, 2002), 157.

${ }^{72}$ Fatmah Taufik Hidayat dan Mohd Izhar Ariff bin Mohd Qasim, "Kaedah Adat Muhakkamah dalam Pandangan Islam: Sebuah Tinjauan Sosiologi Hukum"," Jurnal Sosiologi USK, 9, no. 1 (Juni 2016): 67. 
prove that admitting and accommodating customs were attached to the existence of Islamic law. ${ }^{73}$

\section{Refering to Common Good (mashlahahamah) principle}

Allah, the Almighty, as creator of sharia, makes regulations and laws for human beings through Prophet Muhammad (PBUH) to be used as guidance in the world. The existence of the regulations and laws (al-ahkâm al-syar'iyyah) that present as guidelines and references to reach mashlahah (common good) $)^{74}$ or also means for a greater good. ${ }^{75}$ Therefore, figh scholars agreethat mashlahah is the core of compliance, so that there is a popular proverb ainamâkânat al-mashlahah fa tsammahukm Allah (when there is mashlahah, there is Allah's law). ${ }^{76}$

Islamic law is basically created to reach common good as every Allah's command has maslahah and in every prohibition has mafsadah (hazard) in it. Regulations and laws in Islam are based on two basic rules, such as, jalb almashâlih (generating benefits or mashlahah) and dar' al-mafasid (declining damage). Therefore, it indicates that Allah makes law that will benefit human beings in the world and the hereafter. ${ }^{77}$

Muhammad Arsyad al-Banjari stated his figh concepts in SabilalMuhtadin based on jalb al-mashâlih and dar' al-mafasid, as seen inbuilding construction on graveyard, corpse burial with tabala, constraints in inheritance, food for mourners, floated lavatory, zakat receivers, marriage law, some subject matters in prayers, and muamalah cases.

The aforementioned cases solved in the spirit of common good (mashlahah al-ammah). Al-Banjariunderstood that the essences of Islamic law were jalb al-mashâlih and dar' al-mafasid by implementing maslahahwith a guideline of maqâshid al-syar'i. $\quad{ }^{78}$ According to al-Ghazali, the

${ }^{73}$ Muhammad arsyad al-Banjari, SabilalMuhtadin, 78.

74 Mashlahah means al-shalâh, from root mim in the word shalaha-yashluhu. Additionally, istishlâh is the antonym of istifsâd FuadIfran, Munjid al-Thullâb (Beirut: Dâr al-Fikr, 479M); Jamâl al-Din Muhammad bin Mukarrom al-Anshâry, Lisân al-Arab (Kairo: Dâr al-Mishriyyat, n. d.), juz 3. 348; , t.t.

75 Muhammad Tahir al-Qadri, The Islamic State: True Concept $\mathcal{E}$ Eradicating Misconceptions, (Lahore: Minhaj-ul-Qu'an, 2010).

76Jalâl al-Dîn al-Suyûthi, al-Asybâh wa al-Nazhâir (Beirut: Maktabah, t.t.).

77Yûsuf al-Qardawi, al-Ijtihâd al-Mu'âshir (Dâr al-Tauzi' wa al-Nasyr alIslâmiyyah, 1994), 68.

78Muhammad Arsyad al-Banjari, SabilalMuhtadin, 5. al-Banjari'sfiqh concepts which are based on jalb al-mashâlih and dar' al-mafasid is in-line with a concept stated by Izzuddin bin Abdissalam. See Izz al-Dîn Ibn Abd al-Salâm, Qawấ'id alAhkâmfìMashâlih al-Anâm, jilid I (Kairo: Istiqamah, n.d.),10. 
implementation of maqâshid al-syar'icould beseen from ushûl al-khamsah; hifzh al-din (preserving religion), hifzh al-nafs (preserving humanity), hifzh al-aql (preserving mind or awareness), hifzh al-nasl (preserving descendants), and hifzh al-mâl (preserving prosperity). ${ }^{79}$

\section{G. Conclusion}

Muhammad Arsyad al-Banjari is one of Ulama Nusantara who had greatly contributed to figh concepts throughout his life. One of his monumental books is SabilalMuhtadin that discusses about some subject matters in prayers, and other religious issues, like, aqeeqah, kurban, type of hunted and slaughtered animals, and type of food that allowed or prohibited to be consumed. SabilalMuhtadin consists of two volumes. The first volume has 252 pages and discusses about taharah to requirements to conduct prayers. The second volume has 272 pages and discusses about sujud sahwi to type of food that allowed or prohibited to be consumed. The unique feature of SabilalMuhtadin is in the way al-Banjari accommodated existing Banjarese values or customs.

Al-Banjari used three methods in his ijtihad, namely, ijtihad bayani, ijtihad qiyasi, dan ijtihad istislahi. Some of his ijtihad models can be seen in building construction on graveyard, corpse burial with tabala, constraints in inheritance, food for mourners, floated lavatory, zakat receiver, marriage law, some prayer subject matters, and muamalah cases.

In his ijtihad implementation, al-Banjari relies on several principles, such as, al-adatumuhakkamah (custom is law), jalb al-mashâlih (generating benefits or mashlahah), dar' al-mafasid (declining damage), and taghayyur alahkamyata'allaqu bi taghayyur al-azminahwa al-amkinah(law evolves according to the society's situation and condition). Finally, all of al-Banjari's statements and concepts are based on Syafi'iyyah school.

\section{REFERENCES}

A Dzazuli. Kaidah-Kaidah Fikih: Kaidah-Kaidah Hukum Islam dalam Menyelesaikan Masalah-Masalah yang Praktis,. Jakarta: Kencana, 2007. Abd al-Aziz Azzam. al- Maqasid alShariyyah Fi al Qawaid al-Fiqhiyyah. Kairo: Dar al-Bayan Li al Tibacah Wa al-Nashr, 2001. Abd al-Wahab Khallaf. 'Ilm al-Ushul al Figh. Kairo: Dar al-Qalam, 1978. Abdul Wahhab Khallâf. Ilmu Ushul Al-Fikih. Beirut: Dar Al-kutub alIlmiyah, 2007.

${ }^{79}$ al-Mustashfâ min 'Ilm al-Ushûl, 286. 
- - . Mashâdir Tasyri' Al-Islâmy Fimâ Lâ Nashsha Fih. Kuwait: Dar AlQalam, 1979.

Abû Ishâq al-Syîrazi. al-Luma' fî Ushûl al-Fiqh. Kairo: Muhmmad 'Ali Shabîh, 1999.

Abu Daudi. Muhammad Arsyad Al Banjari. Martapura: Dalam Pagar, 2003.

Abû Hâmid Muhammad al-Ghazâli. al-Mustashfâ min 'Ilm al-Ushûl. Juz II. (Beirut: Dâr al-Fikr, t.t.

"Acceptance and renewal of local culture by the Quran becomes theological arguments for Islamic scholars, especially among fuqaha (fiqh experts). Thus, Islam does not ruin or challenge the existing traditions. In contrary, Islam comes to enrich and makes traditions and cultures to get similar to Islam gradually (tadriji). Quran's universal values, especially on jurisprudence, are translated into social reality faced by the fuqaha. In this case, ijtihad appears as icon of Islamic jurisprudence dynamic development.," t.t.

Ahmad Azhar Basyir. Pokok-Pokok Persoalan Filsafat Hukum Islam. Yogyakarta: UII Press, 2000.

Ahmadi Hasan. Adat Badamai: Interaksi Hukum Islam dengan Hukum Adat Pada Masyarakat Banjar,. Banjarmasin: Antasari Press, 2007.

Amir al-Hajj. al-Taqrîr wa al-Tahrîr fî' 'Ilm al-Ushûl. Juz III. Beirut: Dâr al-Fikr, 1996.

Amir Mu'allim dan Yusdani. Konfigurasi Pemikiran Hukum Islam. Yordania: UII Press, 2005.

Anita Arianti. "Gerakan Pemurnian Islam Syekh Muhammad Arsyad AlBanjari di Kalimantan Selatan" 14, no. 3 (2010).

“Apa itu Islam Nusantara." Diakses 12 September 2019. http://www.muslimedianews.com/2015/04/.

Arfan Abbas. Kaidah-kaidah Fiqh Muamalah dan Aplikasinya dalam Ekonomi Islam dan Perbankan Syariah. Jakarta: Direktorat Pendidikan Tinggi Islam dan Direktorat Jenderal Pendidikan Islam Kementerian Agama RI, 2012.

Azyumardi Azra. Jaringan Ulama Timur Tengah dan Kepulauan Nusantara Abad XVII dan XVIII,. Bandung, Mizan, 1998.

Bambang Subiyakto. "Syekh Muhammad Arsyad Al-Banjari: Upaya dan Ajaran Nilai-Nilai Karakter dalam Pendidikan Ilmu Pengetahuan Sosial." Universitas Pendidikan Indonesia, 2015.

"Basuluh", comes from Arabic vocabulatyal-sulhu, which means peace.," t.t.

Djazuli. Ilmu Figh Penggalian, Perkembangan dan Penerapan Hukum Islam. Jakarta: Kencana Prenada Media Group, 2005. 
Fathullah Munadi. "Mushaf Qiraat Syekh Muhammad Arsyad Al-Banjari Dalam Sejaran Qiraat Nusantra",." Al-Banjari: Jurnal Ilmiah Ilmu-Ilmu Keislaman, 9, no. 1 (2010): 61.

Fathurrahman Azhari. "Dinamika Perubahan Sosial dan Hukum Islam,." Jurnal al-Tahrir Vol. 16., no. No.1 (Mei).

Fatmah Taufik Hidayat, dan Mohd Izhar Ariff bin Mohd Qasim. "Kaedah Adat Muhakkamah dalam Pandangan Islam: Sebuah Tinjauan Sosiologi Hukum",." Jurnal Sosiologi USK, 9, no. 1 (Juni 2016): 67.

Fauziah. "Konsep U'rf dalam Pandangan Ulama Ushul Fiqih: Telaah Historis"." Jurnal Nurani 14, no. 2 (Desember 2004): 17.

Fazlur Rahman. Post Formative Developments in Islam. Karachi: Islamic Studies, 1962.

"From the aforementioned explanation, ijtihad requires texts from the Quran and hadith in the form of nashshs which means words with definite legal provisions and there is no interpretation; and then zhahir which means words with vague meaning and there is possibility of having interpretation. In addition, we need to identify texts from the Quran and hadith which is manthûq (explicit) and mafhûm (implicit). After that, mujtahid needs to pay attention to Prophet Muhammad's behavior and provision, followed by ijmâ' and qiyâs.," t.t.

FuadIfran. Munjid al-Thullâb. Beirut: Dâr al-Fikr, 479M.

Ghufron A Mas'adi. Pemikiran Fazlur Rahman tentang Metodologi Pembaharuan Hukum Islam; Muhammad Khalid Mas'ud, Filsafat Hukum: Studi Tentang Pemikiran Abu Ishaq al-Syatibi (Bandung: Pustaka, 1999), 1. Jakarta: Raja Grafindo Persada, 1997.

Husnul Yaqin. "Syakh Muhammad Arsyad Al-Banjari's Thought On Education"." Journal of Indonesian Islam 5, no. 2 (2011): 336.

Ibn Manzhûr al-Ifriqi. Lisân al- 'Arab. Beirut: Dâr al-Shâdir, t.t.

Ibn Qayyim al-Jawziyah. I'lam al-Muawaqi'in 'an Rabbi al- 'Alamin. Bairut: Dar al-Fikr, 14.

Ibn Rusyd. Bidayat al-Mijtahid wa Nihayat al-Muqrashid. Indonesia: Dar alKutub al-Arrabiyyah, t.t.

Imam Muslim. Shahih Muslim. Beirut: Dar al-Fikr, 1998.

"In swamp area, before the corpse is buried, it is placed in a coffin called tabala in Bajarese tradition. Thus, the size of the grave will be smaller than graves in higher land or non-swamp area (normally 1.5 fathom and 3 cubits)," t.t.

Jaih Mubarok. Kaidah Fiqh: Sejarah dan Kaidah-Kaidah Asasi. Jakarta: PT Raja Grafindo Persada, 2002.

Jalâl al-Dîn al-Suyûthi. al-Asybâh wa al-Nazhâir. Beirut: Maktabah, t.t. 
Jamâl al-Din Muhammad bin Mukarrom al-Anshâry. Lisân al-Arab (Kairo: Dâr al-Mishriyyat, n. d.), juz 3. 348; , t.t.

Khabibi Muhammad Luthfi. "Islam Nusantara: Relasi Islam dan Budaya Lokal." LP2M IAIN Surakarta Vol. 1, Nomor 1, Januari-Juni 2016 (t.t.).

Khabibi Muhammad Luthfi,. "Islam Nusantara: Relasi Islam dan BudayaLokal." IAIN Surakarta 1, Number 1, January - June 2016, . (t.t.): 3.

"King of Tidung or Tarakan kingdom from South-East Dinasty namely Sultan Abdurrasid-the descendant of King of Sulu sultanate," t.t.

Lahmuddin Nasution. Pembaharuan Hukum Islam Dalam Mazhab Syafi'i. Bandung: PT. Remaja Rosdakarya, 2001.

Louis Malouf,. al-Munjid fi al-Lughah. Beirut: Dâr al-Masyriq, 1986.

M. Fahimul Fuad. "Nomenklatur Pemikiran Hukum Syaikh Arsyad AlBanjary." Online Jurnal Publications Stai Darussalam Lampung Vol. 2, no. No. 2 (2013): 89.

Maioen Zubair. Formulasi Nalar Figh Telaah Kaidah Figh Konseptual. Surabaya: Khalista, 2005.

Mohd Azhan Zakaria. "Kitab Zakat Dalam Kitab Sabil Al-Muhtadin Karya Syekh Muhammad Arsyad Al-Banjari Anotasi dan Analisis / Mohd Azhan Zakaria"." University of Malaya, 2015.

M.S. Kadir. Shaikh Muhammad Arshad al-Banjari Pelopor Da'wah Islam di Kalimantan Selatan,. Mimbar Ulama, 1976.

Muhammad Abid al-Jâbiri. al-Dîn wa al-Daulah wa al-Tatbî̀ al-Syarî́ah. Beirut: Markaz Dirasah al-Wahdah al-'Arabiyah, 1996.

Muhammad Abûzahrah, dan al-Imâm Zayd. Hayâtuhwa 'AshruhwaArâ'uhwaFiqhuh. (Kairo: Dâr al-Fikr al- 'Arabi, 1974.

Muhammad Arsyad Al-Banjari, Sabil Al-Muhtadin, Juz II, 83, t.t.

"Muhammad Arsyad al-Banjari Sang Matahari Agama dari Kalimantan," 18 Juli 2013. Republika.

Muhammad ibn 'Ali al-Syawkâni. Irsyâd al-Fukhûl ilâ Tahqîq al-Haqq min 'Ilm al-Ushûl. Beirut: Dâr al-Fikr, t.t.

Muhammad Ibn 'Ali al-Syawkâni. Irsyâd al-FukhûlilâTahqîq al-Haqq Min 'Ilm al-Ushûl. Surabaya: Maktab Sa' adI bnNabhân, t.t.

Muhammad Khalid Mas'ud. Shatibi's of Islamic Law. Islamabad: Islamic Research Institute, 1995.

Muhammad Khudari Bik. Ushûl al-Figh. Beirut: Dar al-Fikr, 1981.

Muhammad Tahir al-Qadri. The Islamic State: True Concept \& Eradicating Misconceptions,. Lahore: Minhaj-ul-Qu'an, 2010.

Munir Fuady. Sosiologi Hukum Kontemporer Interaksi Hukum, Kekuasaan, dan Masyarakat; Lahmuddin Nasution, Pembaharuan Hukum Islam Dalam 
Mazhab Syafi'i (Bandung: PT. Remaja Rosdakarya, 2001), 254. Bandung: Citra Aditya, 2007.

Musa. Tarikh al-Figh al-Islamì. Mesir: Dar-al-Kitab al-'Arabi, 1958.

Muslich Shabir. Pemikiran Syekh Muhammad Arsyad al-Banjari tentang Zakat: Suntingan Teks dan Analisis Intertekstual. Jakarta: Penerbit Nuansa Aulia, 2005.

Nurcholish Madjid. Islam Keindonesiaan dan Modernisasi. Jakarta: Mizan Pustaka, 2009.

Rahmadi. "Jaringan Intelektual Ulama Keturunan Syekh Muhammad Arsyad Ak-Banjari." Al-Banjari: Jurnal Ilmiah Ilmu-Ilmu Keislaman 9, no. 2 (2010): 194.

Saif al-Dîn Abû al-Hasan 'Ali ibn Abî 'Ali ibn Muhammad al-AmidiSaif alDîn Abû al-Hasan 'Ali ibn Abî 'Ali ibn Muhammad al-Amidi. al-Ihkâm. Juz IV, t.t.

Salih bin Fauzan al-Fauzan. Ringkasan Fikih Lengkap, translated. Asmuni,. Jakarta: PT. Darul Falah, 2005.

Sayyid Sabiq. Fikih Sunnah translation. Nor Hasanuddin,. Jilid 4. Jakarta: Pena Pundi Aksara, 2007.

Shaikh Muhammad Arshad al-Banjari. Kitab Sabilal Muhtadin, Jilid 2, terj. Asywadie Syukur,. Surabaya: Bina Ilmu, 2003.

Sudrajat. Ulama pejuang dan ulama petualang: belajar kearifan dari Negeri Atas Angin. Erlangga, 2006.

Syamsudin Arif. Islam Nusantara. Jakarta: Historiografi dan Metodologi, 2000.

Tajuddin al-Subky. Al-Asybah wa al-Nazhair. Beirut: Dar al-Kutub alIlmiyyah, 1991.

Tamrin Dahlan. Kaidah-kaidah Hukum Islam (Kulliyah al-Khamsah). Malang: UIN Maliki Press, 2010.

"Upacara kematian pada Masyarakat Banjar," t.t. http://uunhalimah.blogspot.co.id/2008/06.

Usman Muchlis. Kaidah-Kaidah Istinbath Hukum Islam: Kaidah-Kaidah Ushuliyah dan Fiqhiyah, Jakarta: PT Raja Grafindo Persada, 2002.

Wahbah Zhaily. Al-Fiqh al-Islâmy wa Adillatuhu. Beirut): Dâr Al-Fikr, 1997.

Wilbert E, Maore. Order and Change: Essay in Comparative Sosiology. New York: John Wiley \& Sons, 1967.

Yûsuf al-Qardawi. al-Ijtihâd al-Mu'âshir. Dâr al-Tauzi' wa al-Nasyr alIslâmiyyah, 1994. 
212 | AKADEMIKA, Vol. 24, No. 01 January - June 2019 